\title{
MIRENJE PREMA IZMJENAMA I DOPUNAMA ZAKONA O PARNIČNOM POSTUPKU 2019.
}

Ivana Vrcić, univ. spec. iur.*

\author{
UDK.: 347.919 .1 \\ 347.925 \\ https://doi.org/10.30925/zpfsr.41.1.19 \\ Ur.: 12. siječnja 2020. \\ Pr.: 17. veljače 2020. \\ Stručni rad
}

\begin{abstract}
Sažetak
U radu se prikazuju izmjene i dopune u postupku mirenja prema Noveli Zakona o parničnom postupku iz 2019. Analiziraju se moguća pitanja u praksi koje donose nova pravila o mogućnosti upućivanja stranaka u postupak mirenja tijekom parničnog postupka. Ukazuje se na prednosti i nedostatke uvedenog instituta obveznog mirenja, s osvrtom na mirenje u postupcima po pravnim lijekovima. Analizira se skraćivanje trajanja zastoja postupka u svrhu mirenja zbog ubrzanja i skraćivanja parničnog postupka. Postavlja se pitanje o mogućnostima primjene izvan institucionalnog on-line mirenja u odnosu na propisanu elektroničku komunikaciju sa sudovima.
\end{abstract}

Ključne riječi: postupak mirenja; obvezno mirenje; zastoj postupka; on-line mirenje.

\section{UVOD}

Zakon o izmjenama i dopunama Zakona o parničnom postupku ${ }^{1}$ koji je stupio na snagu 1. rujna 2019. značajno je izmijenio određena pravila postupanja u parničnom postupku, između ostalog i institut mirenja. ZID ZPP/19 donesen je radi otklanjanja problema u primjeni zakona, unaprjeđenju funkcionalizacije pravosudnog sustava, ubrzanja i skraćivanja trajanja sudskih postupka, a time i smanjenja troškova parničnog postupka. ${ }^{2}$ Uvažavajući značaj mirenja kao alternativnog načina rješavanja sporova, izmijenjene su i dopunjene odredbe o mirenju u cilju njegova jačanja i promicanja.

Mirenje je kao pravni institut uvedeno u pravni sustav Republike Hrvatske Zakonom o mirenju iz 2003. (dalje: ZM). ${ }^{3}$ Mirenje je svaki postupak, bez obzira na to provodi li se u sudu, instituciji za mirenje ili izvan njih, u kojem stranke nastoje

\footnotetext{
* Ivana Vrcić, univ. spec. iur., predavačica, Veleučilište VERN, Zagreb; ivrcic@yahoo.com.

1 Zakon o izmjenama i dopunama Zakona o parničnom postupku, Narodne novine, br. 70/19., dalje u tekstu: ZID ZPP/19.

2 Prijedlog Zakona o izmjenama i dopunama Zakona o parničnom postupku, Vlada Republike Hrvatske, ožujak 2019.

3 Zakon o mirenju, Narodne novine, br. 163/03.
} 
sporazumno riješiti spor s pomoću jednog ili više izmiritelja koji strankama pomažu postići nagodbu, bez ovlasti da im nametnu obvezujuće rješenje, a provodi se na način o kojem su se stranke sporazumjele. ${ }^{4}$

Nakon njegova uvođenja, ovaj je institut doživio nekoliko zakonskih izmjena i dopuna. Sukladno s navedenim pravnim uređenjem mirenja, odredbe o mirenju uvedene su u Zakon o parničnom postupku ${ }^{5}$ te su u svrhu afirmacije, uređenja $\mathrm{i}$ primjene mirenja u parnici nekoliko puta mijenjane.

Tako posljednja izmjena ZID ZPP/19 donosi pravila kojima se mijenjaju dosadašnje odredbe te se uz postojeće dobrovoljno mirenje, uvode i novi oblici obveznog mirenja.

Novim se odredbama želi osnažiti mirenje kao jedan od alternativnih načina rješavanja sporova na način da se sucima omogući da stranke upute ili samo potaknu na pokretanje postupka mirenja pri sudu ili izvan njega te se postupovnim odredbama propisuje način upućivanja, postupanja i pravna snaga sklopljene nagodbe u postupku mirenja. ${ }^{6}$

Za razliku od drugih noveliranih odredaba ZPP-a koje se neće primjenjivati na postupke pokrenute prije stupanja na snagu ZID ZPP/19, nova se pravila o mirenju primjenjuju na sve postupke u tijeku. ${ }^{7}$

\section{NOVA PRAVILA O MIRENJU}

Nova pravila o mirenju propisuju da sud tijekom postupka može uvažavajući sve okolnosti, posebno interes stranaka i trećih osoba povezanih sa strankama te trajnost njihovih odnosa i upućenost jednih na druge, na ročištu ili izvan ročišta rješenjem uputiti stranke da u roku od osam dana pokrenu postupak mirenja ili rješenjem strankama predložiti rješavanje spora u postupku mirenja. ${ }^{8}$

Takvim je rješenjem prijašnja odredba prema kojoj je sud tijekom cijelog parničnog postupka mogao strankama samo predložiti da spor riješe u postupku mirenja pri sudu ili izvan suda, znatno proširena davanjem mogućnosti sudu da strankama naloži pokretanje postupka mirenja.

Sudu se novim uređenjem daje dispozicija da uvažavajući sve navedene okolnosti, rješenjem uputi stranke na pokretanje postupka ili ih, ovisno o okolnostima, potakne na mirenje predlažući rješavanje spora u postupku mirenja.

Dakle, sudu je dana mogućnost da u svakom sporu naloži strankama pokretanje postupka mirenja, pred sudom ili izvan suda u nekom od centara za mirenje. Pri tome treba procijeniti okolnosti u konkretnom slučaju.

Iako ova odredba uvelike doprinosi afirmaciji mirenja, nije moguće predvidjeti

4 Zakon o mirenju, Narodne novine, br. 18/11, čl. 3. i 9.

5 Zakon o parničnom postupku, Narodne novine, br. 53/91., 91/92., 112/99., 88/01., 117/03., 88/05., 2/07., 84/08., 96/08., 123/08., 57/11., 148/11. - (pročišćeni tekst), 25/13. i 89/14. Odluka Ustavnog suda Republike Hrvatske; dalje u tekstu: ZPP.

6 Prijedlog Zakona o izmjenama i dopunama Zakona o parničnom postupku, Vlada Republike Hrvatske, ožujak 2019.

7 Čl. 117. st. 2. ZID ZPP/19.

8 Čl. 186. d st. 1. ZPP. 
reakciju stranaka te njihovu stvarnu volju i namjeru za rješavanjem spora mirenjem. Moguće je da će određen broj stranaka pristupiti mirenju isključivo kako bi zadovoljile formu bez namjere postizanja rješenja. Tomu dodatno pogoduje i ne postojanje sankcija za navedeno postupanje.

Stranke koje su upućene na postupak mirenja dužne su pokrenuti postupak u roku od osam dana. Može se zaključiti da se propisivanjem osmodnevnog roka želi postići ubrzanje i funkcionalizacija postupka, jer se strankama vremenski određuje rok do kojeg trebaju pokrenuti postupak mirenja. Navedena odredba otvorit će u praksi niz pitanja.

Za očekivati je da će u slučaju obveznog mirenja sud na mirenje uputiti sve stranke u postupku. Tako bi se moglo zaključiti iz ratia odredbe, a i sama priroda mirenja te razlozi oportuniteta upućuju na takav zaključak.

Neovisno o navedenom, nije na odmet razmotriti i drugu teoretsku mogućnost. Može li sud na pokretanje postupka mirenja uputiti samo jednu ili samo neke od stranaka u sporu, dakle ne sve stranke?

Naime, u odredbi članka 186. d stavka 1. navodi se da sud može uputiti stranke da pokrenu postupak mirenja, a u stavku 9. govori se o stranci koja je upućena u postupak mirenja.

Ako su sve stranke upućene pokrenuti postupak mirenja, trebaju li to učiniti zajedničkim prijedlogom, svaka stranka zasebno ili je dostatno da to učini jedna od stranaka, a ako je tako, koja? Čini se da nema zapreke da to učine zasebno, a svakako bi bilo dobro da to učine zajedničkim prijedlogom. Ako su upućene obje, odnosno sve stranke, stranka koja propusti podnijeti prijedlog gubi pravo tražiti naknadu daljnjih troškova postupka pred sudom prvog stupnja.

Naime, odredbom članka 6. ZM-a propisano je da mirenje počinje prihvatom prijedloga za provođenje postupka mirenja. Ako se stranke nisu drukčije sporazumjele, druga se stranka o prijedlogu za provođenje mirenja mora izjasniti u roku od 15 dana od dana kada je primila prijedlog za provođenje mirenja, ili u drugom roku za odgovor naznačenom u prijedlogu. Ako se druga stranka o prijedlogu za provođenje mirenja ne izjasni u danom roku, smatrat će se da je prijedlog za mirenje odbijen.

Postavlja se i pitanje je li osmodnevni rok instruktivne ili obvezujuće prirode?

Jedno od mogućih tumačenja bilo bi da je taj rok prekluzivne prirode u odnosu na pravo traženja naknade daljnjih troškova postupka pred sudom prvog stupnja. Međutim, taj rok bi trebao biti instruktivan u odnosu na postupak mirenja, jer se neovisno o volji suda, stranke mogu miriti i nagoditi tijekom cijeloga parničnog postupka.

Treba razmotriti i pitanje troškova ako stranka koja je bila upućena pokrenuti postupak mirenja pokrene postupak nakon isteka osmodnevnog roka, primjerice deveti ili petnaesti dan?

Ako je neovisno o tome mirenje bilo uspješno, stranke će nagodbom obuhvatiti i troškove postupka.

Međutim, u slučaju da druga strana ne prihvati prijedlog rješenja spora mirenjem ili se mirenje ne okonča nagodbom, stranka koja je zakasnila s prijedlogom za mirenje trebala bi izgubiti pravo tražiti naknadu daljnjih troškova postupka pred sudom prvog 
stupnja.

Rješenja kojima sud upućuje stranke na postupak mirenja ili predlaže mirenje, sud može donijeti tijekom parničnog postupka, na ročištu ili izvan njega. ${ }^{9}$ Navedena rješenja su rješenja o upravljanju postupkom protiv kojih stranke nemaju pravo žalbe. ${ }^{10}$

\subsection{Postupak mirenja pred sudom}

Ako stranke suglasno predlože ili prihvate rješavanje spora u postupku mirenja pred sudom, bez odgode će se odrediti sastanak radi pokušaja mirenja na koje se pozivaju stranke, njihovi zastupnici i punomoćnici, ako ih imaju. ${ }^{11}$

Navedena odredba nije znatnije mijenjana u odnosu na prijašnje rješenje, osim što je pojam ,ročište“ radi pokušaja mirenja terminološki zamijenjen pojmom „sastanak" radi pokušaja mirenja. Isto tako treba napomenuti da navedena odredba ne sprječava stranke da predlože rješavanje spora u postupku mirenja u nekom od centara za mirenje izvan suda, odnosno bilo gdje, bez obzira na način i forum rješavanja, jer im je ta mogućnost dana odredbama članka 186. f i g. ZPP-a.

Sastanak radi pokušaja mirenja pred sudom odredit će se bez odgode.

Uzimajući u obzir činjenicu da sudac koji vodi postupak ne može biti izmiritelj i ne može utjecati na izmiritelja u postupku mirenja, postavlja se pitanje koliko brzo će biti moguće održati taj sastanak. Postupak mirenja pred sudom vodi izmiritelj određen s liste izmiritelja koju utvrđuje predsjednik suda. ${ }^{12}$ Izmiritelj određuje termin sastanka i poziva stranke, njihove zastupnike i punomoćnike, ako ih stranke imaju, a ne parnični sudac.

Postoji mogućnost da će predlože li stranke mirenje, u praksi morati pričekati da ga izmiritelj zakaže, ovisno o rasporedu i opterećenosti drugim predmetima. S obzirom na novu mogućnost da sud uputi stranke u postupak mirenja, opravdano je očekivati veći broj postupaka mirenja, što može utjecati na vremenski okvir zakazivanja sastanka radi pokušaja mirenja.

Novim se odredbama detaljno propisuje sudjelovanje izmiritelja u postupku mirenja. Izmiritelj ne može sudjelovati u postupku mirenja u parničnom predmetu koji mu je dodijeljen. Ako se postupak mirenja ne okonča sklapanjem nagodbe, izmiritelj ne smije sudjelovati u tom sporu u bilo kojem svojstvu. ${ }^{13}$ Slično je rješenje već i od ranije sadržano u odredbi članka 16 . ZM-a.

Uspješan postupak mirenja završava nagodbom. Nagodba sklopljena u postupku mirenja pred sucem izmiriteljem smatra se sudskom nagodbom. ${ }^{14}$

\subsection{Obvezno mirenje}

Postupak mirenja obvezatan je u sljedećim slučajevima:

9 Čl. 186. d st. 2. ZPP., u vezi s čl. 186. d.st. 1. ZPP.

10 Čl. 186. d st. 9. ZPP.

11 Čl. 186. d st. 3. ZPP.

12 Čl. 186. d st. 4. ZPP.

13 Čl. 186. d st. 5. ZPP.

14 Čl. 186. d st. 6. ZPP. 
- ako sud uputi stranke na pokretanje postupka mirenja $\mathrm{i}^{15}$

- ako su obje stranke ili dionička društva ili pravne osobe kojima je većinski član Republika Hrvatska ili jedinica lokalne i područne (regionalne) samouprave. ${ }^{16}$

U prvom slučaju upućivanje stranaka na postupak mirenja, ovisno je o procjeni suda koji će uvažavajući sve okolnosti, posebno interes stranaka i trećih osoba vezanih za stranke te trajnost njihovih odnosa i upućenost jednih na druge, odlučiti hoće li stranke uputiti na mirenje, iako to svakako nije obvezan.

U drugom slučaju sud će po primitku odgovora na tužbu uputiti stranke da u roku od osam dana pokrenu postupak mirenja. Propisana je obveza suda da u tim slučajevima kad su obje stranke ili dionička društva ili pravne osobe s većinskim članstvom Republike Hrvatske, odnosno jedinica lokalne i područne (regionalne) samouprave, neovisno o svim drugim okolnostima spora, uputi stranke na mirenje. Obvezno mirenje u ovom slučaju neovisno je o procjeni suda i temelji se isključivo na objektivnoj činjenici svojstva stranke.

U praksi se mogu pojaviti pitanja o tumačenju ove odredbe. Prema gramatičkom tumačenju postupak mirenja obvezan je kada su obje stranke dionička društva neovisno je li u njima većinski član Republika Hrvatska, odnosno jedinica lokalne i područne (regionalne) samouprave.

Takvo bi tumačenje moglo nadalje rezultirati i pitanjem ustavnopravne ravnopravnosti stranaka pred sudom. Jesu li dionička društva radi zakonom propisnog obveznog mirenja privilegirana ili nasuprot tome stavljena u nepovoljniji položaj u odnosu na druge stranke u sporu (primjerice d.o.o., fizičke osobe ili slično).

Odredba nadalje govori o sporu u kojem su obje stranke dionička društva. U tom se smislu postavlja pitanje što u situaciji kada u sporu ima više stranaka od kojih su neke dionička društva, a neka ne?

Drugo tumačenje moglo bi ići u pravcu da je mirenje obvezno samo u situacijama kada su stranke dionička društva odnosno pravne osobe, ali uz pretpostavku da je u njima većinski član Republika Hrvatska ili jedinice lokalne i područne (regionalne samouprave). Argumenti u pravcu takvog tumačenja mogli bi se zasnivati na zaštiti javnog interesa.

Stranka koja je upućena pokrenuti postupak mirenja, a ne pristupi sastanku radi pokušaja mirenja, gubi pravo tražiti naknadu daljnjih troškova postupka pred sudom prvog stupnja. ${ }^{17}$

Ova bi odredba mogla u praksi rezultirati određenim dvojbama. Postavlja se pitanje u kojim sve slučajevima gubi pravo traženja naknade daljnjih troškova postupka pred sudom prvog stupnja?

Iz odredbe jasno proizlazi da je stranka koja je upućena pokrenuti postupak mirenja obvezna pokrenuti taj postupak u roku od osam dana te pristupiti sastanku radi pokušaja mirenja.

U praksi su moguće i drukčije, složenije situacije. Što ako upućena stranka u

15 Čl. 186. d st. 1. ZPP.

16 Čl. 186. d st. 7. ZPP.

17 Čl. 186. d st. 8. ZPP. 
roku predloži ali druga stranka ne prihvati mirenje?

Naime, sastanak radi pokušaja mirenja pred sudom odrediti će se tek ako stranke ili suglasno predlože ili prihvate rješavanje spora u postupku mirenja.

Dakle, iako je stranka koja je upućena pokrenuti postupak mirenja to učinila, da bi mogla pristupiti sastanku radi pokušaja mirenja, druga ili druge stranke moraju prihvatiti takav način rješavanja spora.

U suprotnom sastanak neće biti određen, a stranka koja je upućena pokrenuti postupak mirenja neće moći pristupiti sastanku. Posljedično, ne bi smjela izgubiti pravo tražiti naknadu daljnjih troškova postupka pred sudom prvog stupnja, iako nije pristupila sastanku radi pokušaja mirenja, kako je to izrijekom propisano.

Svrhovito bi bilo razmotriti i položaj stranke koja nije bila upućena pokrenuti mirenje, ali nije prihvatila predloženo mirenje od druge stranke koja je bila upućena $i$ koja ga je u roku pokrenula?

Gubi li ta druga stranka, koja nije prihvatila mirenje, pravo tražiti naknadu daljnjih troškova postupka pred sudom prvog stupnja?

Prema sadržaju odredbe čl. 186. d st. 9. ZPP-a čini se da ne. Stranka koja nije bila upućena pokrenuti postupak mirenja, ne može pristupiti sastanku radi pokušaja mirenja, jer zbog njezinog odbijanja mirenja, taj sastanak neće biti niti određen.

Drugim riječima, stranka koja nije bila upućena pokrenuti postupak mirenja, može bez sankcija za trošak odbiti prijedlog za mirenje.

Gubitkom daljnjih parničnih troškova pred prvostupanjskim sudom nastoji se dodatno stimulirati stranke na pokušaj mirenja. Jasno i nedvosmisleno se po načelu kauzaliteta penalizira pasivno ponašanje stranaka.

Odluka o visini troškova, dakle, ne ovisi o subjektivnom nastojanju stranaka da spor riješe mirnim putem, već je vezana isključivo na činjenicu jesu li stranke pristupile sastanku radi pokušaja mirenja. Time se u svrhu poticanja mirnog rješenja spora, pojednostavljuje i izbjegava komplicirano računanje troškova do kojeg bi moglo doći ako da su ovisni o nastojanju stranaka za rješavanje spora mirnim putem.

Stranci koja nije pristupila sastanku radi pokušaja mirenja, sud je dužan odbiti zahtjev za naknadu daljnjih troškova prvostupanjskog postupka, pa čak i u situaciji da je ta stranka u cijelosti uspjela u parnici.

Opravdano je očekivati da će u postupcima s većom vrijednosti predmeta spora, a samim time i većim troškovima postupka, stranke biti aktivnije i barem pristupiti sastanku radi pokušaja mirenja.

Takvo rješenje zasigurno ima prednosti jer će svakako primorati jedan dio parničnih stranaka na pokušaj mirenja. Uspostavljanjem obveznog sastanka s izmiriteljem, omogućiti će strankama uz prisutnost njihovih zastupnika i punomoćnika, upoznavanje s mogućnostima i prednostima mirenja u konkretnom sporu.

Pritom treba istaknuti da neovisno o predmetu spora u postupku mirenja stranke mogu sveobuhvatno urediti i svoje druge odnose. U mirenju je spor moguće riješiti novacijom, kompenzacijom, moguće je obuhvatiti i neke buduće obvezno pravne odnose između stranaka što znatno proširuje mogućnost sklapanja nagodbe. Također, treba imati na umu da u slučaju uspješno sklopljene nagodbe stranke imaju mogućnost i nadalje zadržati dobre i uspješne poslovne odnose. Tako, primjerice prodavatelj i 
nadalje zadržava potencijalnog kupca, ne gubi dio tržišta, što sve posredno utječe na poslovni ugled stranaka.

Posebno treba istaknuti da se sklapanjem uspješne nagodbe još u postupku pred prvostupanjskim sudom bitno vremenski skraćuje neizvjesnost financijskih i poslovnih tijekova između stranaka u postupku. Uspješno mirenje uz smanjene troškove, nedvojbeno ima i prednost u odnosu na brzinu u usporedbi s dužinom parničnog postupka od njegovog pokretanja do pravomoćnosti sudske odluke.

Međutim, postavlja se pitanje psihološkog odnosa stranaka prema mirenju koje iz neobvezatnog i dobrovoljnog postaje nametnuto i obvezatno. Sama fizička prisutnost stranaka radi izbjegavanja penalizacije u vidu gubitka daljnjih troškova postupka, nije dostatna za uspješno rješenje spora koje ovisi o mnogim čimbenicima, kao što su, prije svega, namjera i volja stranaka za mirnim rješenjem spora, vještine izmiritelja i niz drugih.

Treba imati u vidu da spremnost na mirenje ne ovisi isključivo o subjektivnom odnosu stranaka već je nekad uvjetovana i objektivnim okolnostima. Iako su stranke katkad voljne pomiriti se, objektivno mogu u tome biti spriječene jer nemaju financijskih ili materijalnih mogućnosti ispuniti obvezu iz moguće nagodbe koju bi inače htjele sklopiti. U tom slučaju stranka će samo iz formalnih razloga pristupiti sastanku radi pokušaja mirenja kako bi izbjegla penalizaciju troškova, iako je pri tome svjesna da neće pristati na nagodbu.

\subsection{Mirenje u postupcima po pravnim lijekovima}

U pogledu mirenja pred drugostupanjskim sudom, zadržane su odredbe prema kojima stranke mogu nakon podnošenja redovitog pravnog lijeka suglasno podnijeti prijedlog za rješavanje spora u postupku mirenja pred sucem izmiriteljem suda nadležnog za odlučivanje o pravnom lijeku. ${ }^{18}$ To može bilo koja od stranaka ili sve stranke zajedno. Pritom je inicijativa na strankama.

Iz ove se odredbe može zaključiti da zakonodavac nije namjeravao uvesti obvezno mirenje pred drugostupanjskim sudovima, odnosno Vrhovnim sudom Republike Hrvatske.

Međutim, postavlja se pitanje ima li drugostupanjski, odnosno Vrhovni sud Republike Hrvatske ovlaštenja prema kojima bi mogao obvezati stranke na pokušaj mirenja ili rješenjem strankama predložiti rješavanje spora u postupku mirenja.

Odredba članka 186. d stavak 2. ZPP-a propisuje da rješenja iz stavka 1. ovoga članka sud može donijeti tijekom parničnog postupka, dakle i u stadiju redovitih i izvanrednih pravnih lijekova. ${ }^{19}$

Izričito se navodi riječ rješenja iz stavka 1., a to su rješenje o upućivanju stranaka da u roku od osam dana pokrenu postupak mirenja i rješenje o predlaganju rješavanja spora u postupku mirenja.

Prema takvom tumačenju moglo bi se zaključiti da i drugostupanjski i Vrhovni

18 Čl. 186. e st. 1. ZPP.

19 Siniša Triva i Mihajlo Dika, Zakon o parničnom postupku - redakcijski pročišćeni tekst s interpretativnim i komentarskim bilješkama i stvarnim kazalom, 24. izmijenjeno i dopunjeno izd. prema stanju na dan 26. listopada 2019., (Narodne novine, Zagreb, 2019.), 216. 
sud Republike Hrvatske imaju ovlaštenja obvezati stranke na pokušaj mirenja ili predložiti rješavanje spora mirenjem.

U tom slučaju upitna je svrhovitost odredbe članka $186 \mathrm{~d}$. stavak 8. ZPP-a o gubitku prava traženja naknade daljnjih troškova postupka pred sudom prvog stupnja. Logično bi bilo da je u tom slučaju propisan gubitak prava traženja naknade daljnjih troškova postupka, bez ograničenja da se to odnosi isključivo na postupak pred sudom prvog stupnja.

Izmiritelj ne može sudjelovati u postupku mirenja u parničnom predmetu koji mu je dodijeljen radi odlučivanja o pravnom lijeku, ${ }^{20}$ kao što niti parnični sudac prvostupanjskog suda ne može sudjelovati u postupku mirenja u parničnom predmetu koji mu je dodijeljen. Isto tako, ako se postupak mirenja ne dovrši sklapanjem nagodbe, izmiritelj ne smije sudjelovati u tom sporu u bilo kojem svojstvu. ${ }^{21}$ Za postupke mirenja koji se provode u sudovima, propisana je odgovarajuća primjena odredaba zakona koji uređuje postupak mirenja, dakle, ZM-a. ${ }^{22}$

Za razmotriti je situaciju u kojoj je tijekom prvostupanjskog postupka pokušaj mirenja bio bezuspješan. Dakle, kada je prvostupanjski sud donio odluku koja je u žalbenom postupku ukinuta i predmet vraćen prvostupanjskom sudu na ponovno odlučivanje, postavlja se pitanje bi li prvostupanjski sudac, imajući u vidu izmijenjene okolnosti spora, mogao ponovno uputiti stranke na postupak mirenja?

\subsection{Mirenje u centrima izvan suda}

Stranke, kao i do sada, imaju mogućnost tijekom parničnog postupka pokrenuti postupak mirenja u nekom od centara za mirenje izvan suda. Za navedeni je način mirenja potreban suglasan prijedlog stranaka, pa ako stranke suglasno predlože rješavanje spora u izabranom centru za mirenje, sud će zastati s postupkom uz odgovarajuću primjenu pravila o zastoju postupka. ${ }^{23}$

Strankama je ostavljena mogućnost izbora mirenja u sudu ili pred izabranim centrom za mirenje uz propisana vremenska ograničenja rokovima o zastoju postupka istekom kojih je potrebno dovršiti postupak mirenja. Pritom treba uzeti u obzir da zastoj postupka radi pokušaja mirnog rješenja spora može ukupno trajati najduže 180 dana.

Strankama ostaje procijeniti i izabrati za njih najbolju mogućnost između suda i centra za mirenje. Pritom je nužno napomenuti da je mirenje u sudu potpuno besplatno, dok mirenje u centrima može zahtijevati podmirivanje određenih troškova postupka.

Ako se postupak mirenja pred izabranim centrom za mirenje izvan suda dovrši sklapanjem nagodbe, stranke na temelju te nagodbe mogu pred sudom koji je zastao s postupkom sklopiti sudsku nagodbu. ${ }^{24}$

Naime, nagodba sklopljena pred izabranim centrom za mirenje izvan suda može ali i ne treba imati svojstvo ovršne isprave. Članak 13. stavak 2. ZM-a određuje da je 
nagodba sklopljena u postupku mirenja ovršna isprava samo ako je u njoj utvrđena obveza na činidbu o kojoj se stranke mogu nagoditi te ako sadrži izjavu obvezanika o neposrednom dopuštenju ovrhe (klauzulu ovršnosti). Ovi uvjeti moraju biti kumulativno ispunjeni.

Nasuprot tome, odredbom čl. 23. st. 1. Ovršnog zakona ${ }^{25}$ određeno je da je ovršna isprava i ovršna sudska nagodba.

\subsection{Izvaninstitucionalno mirenje (bez obzira na način i forum rješavanja)}

Iz naprijed izloženih zakonskih odredaba proizlazi da ZPP predviđa mirenje pred sudom i mirenje u nekom od centara za mirenje izvan suda, no moglo bi se zaključiti da ostavlja i mogućnost izvan institucionalnog mirenja, bez obzira na način i forum rješavanja.

Članak 186. g ZPP-a propisuje da stranke mogu tijekom parničnog postupka suglasno zatražiti od suda zastoj radi pokušaja mirnog rješenja spora, bez obzira na način i forum rješavanja.

Imajući u vidu ovu odredbu postavlja se pitanje bi li stranke udovoljile rješenju suda iz članka 186. $d$ kada bi postupak mirenja pokrenule izvan suda, odnosno centara za mirenje, tj. bez obzira na način i forum rješavanja.

Primjerice to bi moglo biti mirenje pred strukovnim udrugama, fizičkim osobama izmiriteljima koji djeluju izvan centara za mirenje, on-line mirenje (e-mirenje) itd.

Sve ovo ima posebnu važnost u odnosu na sve veću prisutnost on-line mirenja u svijetu, formi u kojoj se komunikacija među strankama i postupak mirenja odvija elektroničkim putem $\mathrm{u}$, tzv. virtualnoj stvarnosti.

Imajući u vidu aktualne izmjene ZPP-a o elektroničkoj komunikaciji pred sudovima postavlja se pitanje o valjanosti takvog pokušaja mirenja u kontekstu odredbe članka 186. d. ZPP-a. Ako bi se uzelo da je tome tako, na koji će se način dokazati da je pokrenut postupak mirenja, je li pokrenut u roku od osam dana, je li određen sastanak radi pokušaja mirenja te jesu li i koje od stranaka pristupile tom sastanku i jesu li uredno pozvane?

Potencijalne prednosti on-line mirenja, posebice među trgovcima, gotovo da je nepotrebno isticati. Dostatno je samo navesti brzinu takvoga postupka, uštede u troškovima, mogućnost rješavanja sporova iz vlastitog prostora, izbjegavanje mogućih neugodnih susreta s protivnom stranom.

\subsection{Zastoj postupka}

Kada stranke suglasno predlože provođenje postupka mirenja u nekom od centara za mirenje izvan suda, sud će zastati s postupkom i primijeniti odredbe o zastoju postupka. Međutim, zastoj mogu suglasno zatražiti i stranke tijekom parničnog postupka radi pokušaja mirnog rješenja spora, bez obzira na način i forum rješavanja. ${ }^{26}$ Zastoj može trajati najduže 60 dana, a sud ga može na suglasni obrazloženi

25 Ovršni zakon, Narodne novine, br. 112/12., 25/13., 93/14., 55/16., 73/17.

26 Čl. 186. g st. 1. ZPP. 
prijedlog stranaka, podnesen prije proteka roka čije se produljenje traži, jednom produžiti za određeno vrijeme, a najviše za daljnjih 120 dana. ${ }^{27}$

Ako nijedna stranka nakon proteka rokova zastoja na poziv suda ne predloži nastavak postupka u roku od 15 dana, smatrati će se da je tužba povučena. ${ }^{28}$ Do takvog presumiranog povlačenja tužbe dolazi tek ako na poziv suda izostane prijedlog bilo koje stranke u sporu za nastavkom postupka.

Prema ranijim odredbama zastoj je mogao trajati godinu dana i bilo ga je moguće jednom produžiti. Novim pravilima o zastoju rokovi su znatno su skraćeni. Time se svakako doprinosi ubrzanju postupka, pa se opravdanost skraćivanja rokova zastoja može pravdati razlozima za ubrzanjem i skraćivanjem parničnih postupaka.

Međutim, nije propisano postupanje suda ako se postupak mirenja ne okonča u zadanom vremenskom ograničenju. Može se zaključiti da su stranke nakon proteka rokova zastoja postupka, iako još nisu postigle mirno rješenje, na poziv suda primorane zatražiti nastavak postupka, jer će se u protivnom smatrati da je tužba povučena.

Iz navedenih se odredaba može zaključiti da je pravilima o zastoju postupka vremenski ograničen postupak mirenja u centrima za mirenje, dok izričita primjena navedenih pravila nije propisana za postupke mirenja pred sudom, već jedino ako stranke tijekom parničnog postupka suglasno zatraže od suda zastoj postupka zbog pokušaja mirnog rješenja spora.

\section{UMJESTO ZAKLJUČKA}

ZID-om ZPP/19 detaljnije su razrađena pravila o mirenju uz istodobnu odgovarajuću primjenu odredaba Zakona o mirenju. Stranke i dalje, prema vlastitom izboru, mogu provoditi mirenja pred prvostupanjskim sudom, pred drugostupanjskim sudom ili izvan suda u centrima za mirenje.

Novim je odredbama uvedeno i obvezno mirenje kojim se osnažuje institut mirenja jer sud može u svim stadijima postupka uputiti stranke na mirno rješavanje spora.

Time je u odnosu na dosadašnje rješenje prema kojem je sud mogao samo predložiti strankama pokušaj mirnog rješenja spora, dana sudovima veća ovlast, propisivanjem mogućnosti upućivanja stranaka na pokretanje postupka mirenja. Navedeni način doprinosi afirmaciji mirenja uspostavom njegove šire primjene.

Uvođenjem ovakve mogućnosti, dosadašnji se dobrovoljni model mirenja pretvara u obvezni, barem u pogledu prisustvovanja stranaka na prvom sastanku s izmiriteljem. Opravdano je očekivati da će stranke pristupiti prvom sastanku $\mathrm{s}$ izmiriteljem zbog prijetnje gubitka naknade daljnjih troškova postupka, što $\mathrm{u}$ parnicama s većim vrijednostima predmeta spora može biti otegotna okolnost.

Takav model zasigurno ima prednosti jer omogućuje upoznavanje stranaka $\mathrm{s}$ postupkom mirenja i njegovim prednostima te mogućnostima mirenja u konkretnom sporu.

Međutim, nije moguće u potpunosti utjecati na postupanje stranaka, odnosno

27 Čl. 186. g st. 2. ZPP.

28 Čl. 186. g st. 3. ZPP. 
na njihovu pravu volju za mirnim rješenjem spora, pa ni uvođenjem takvog modela mirenja. Moguće je da će određen broj stranaka samo formalno pristupiti sastanku kako bi izbjegle penalizaciju i zadovoljile formu, bez stvarne namjere rješavanja spora. Postavlja se pitanje hoće li obvezivanje stranaka na mirenje, koje bi po svojoj prirodi trebalo biti dobrovoljno i neformalno, polučiti željene rezultate?

U odnosu na propisanu elektroničku komunikaciju u parničnom postupku, trebalo bi razmisliti i o mogućnostima on-line mirenja, uvažavajući brojne prednosti, primjerice dodatne uštede vremena i troškova, koje donosi takav način mirenja.

\section{LITERATURA}

1. Ovršni zakon, Narodne novine, br. 112/12., 25/13., 93/14., 55/16., 73/17.

2. Prijedlog Zakona o izmjenama i dopunama Zakona o parničnom postupku, Vlada Republike Hrvatske, ožujak 2019.

3. Triva, Siniša i Dika Mihajlo, Zakon o parničnom postupku - redakcijski pročišćeni tekst s interpretativnim i komentarskim bilješkama i stvarnim kazalom, 24. izmijenjeno i dopunjeno izd. prema stanju na dan 26. listopada 2019., Zagreb: Narodne novine, 2019.

4. Zakon o izmjenama i dopunama Zakona o parničnom postupku, Narodne novine, br. 70/19

5. Zakon o mirenju, Narodne novine, br. $18 / 11$

6. Zakon o parničnom postupku, Narodne novine, br. 53/91., 91/92., 112/99., 88/01., 117/03., 88/05., 2/07., 84/08., 96/08., 123/08., 57/11., 148/11. - pročišćeni tekst, 25/13. i 89/14. Odluka Ustavnog suda Republike Hrvatske. 


\title{
Ivana Vrcić*
}

\author{
Summary
}

\section{MEDIATION UNDER THE AMENDMENTS OF THE CIVIL PROCEDURE ACT OF 2019}

The paper analyses amendments to the mediation procedure according to the Novel of the Civil Procedure Act of 2019. It presents possible issues of practice brought about new rules on the possibility of referring parties to the mediation procedure during litigation. The advantages and disadvantages of the introduced mandatory mediation institute are pointed out, with reference to mediation in remedies proceedings. The article analyses shortening of the length of the delay in civil actions for the purposes of mediation for speeding up and shortening the litigation. The question arises as to the possibilities of application beyond institutional on-line mediation in relation to the prescribed electronic communication with the courts.

Keywords: mediation procedure; mandatory mediation; delay in civil actions; on-line mediation.

Zusammenfassung

\section{MEDIATION GEMÄSS DEN ÄNDERUNGEN UND ERGÄNZUNGEN DES ZIVILPROZESSGESETZES VON 2019}

In diesem Beitrag werden die Änderungen und Ergänzungen im Mediationsverfahren gemäß der Novelle des Gesetzes über Zivilprozessverfahren von 2019 dargestellt. Es werden potentielle Fragen, welche in der Praxis der Anwendung von neuen Regeln über die Möglichkeit, den Parteien während des Zivilprozesses ein Mediationsverfahren vorzuschlagen, auftauchen können, analysiert. Es werden Vor- und Nachteile des eingeführten Instituts der Pflichtmediation besprochen, wobei man auch auf Mediation als Rechtsmittel hinweist. Ebenfalls wird die Verkürzung der Dauer der Verzögerungen im Zivilprozess wegen Mediation analysiert. Der Beitrag bespricht auch die Möglichkeit der außerinstitutionellen Online-Mediation bezüglich der vorgeschriebenen elektronischen Kommunikation mit Gerichten.

Schlüsselwörter:Mediationsverfahren; Pflichtmediation; Verzögerung im Prozess; Online-Mediation.

* Ivana Vrcić, univ. spec. iur., Lecturer, VERN University, Zagreb; ivrcic@yahoo.com. 
Riassunto

\section{LA CONCILIAZIONE SECONDO LE MODIFICHE E LE INTEGRAZIONI DELLA LEGGE SUL PROCESSO CIVILE DEL 2019.}

Nel lavoro si presentano le modifiche apportate al processo di conciliazione introdotte dall'emendamento della Legge sul processo civile ed avvenute nel 2019. $\mathrm{Si}$ analizzano le possibili questioni aperte nella prassi riguardo all'introduzione delle nuove regole che offrono la possibilità di istruire le parti al processo di conciliazione durante il processo civile. Si segnalano vantaggi e svantaggi del modificato istituto di conciliazione obbligatoria, con riferimento alla conciliazione attuata nella procedura di ricorso. Si analizza la riduzione della durata della sospensione del processo ai fini della conciliazione per accelerare ed abbreviare il processo civile. Si pone anche la questione delle possibilità d'applicazione della conciliazione on-line non istituzionalizzata in relazione alla prescritta comunicazione elettronica con le corti.

Parole chiave: processo di conciliazione; conciliazione obbligatoria; sospensione del processo; conciliazione on-line. 
